\title{
GOVERNMENT EXPENDITURE, ECONOMIC GROWTH AND MANPOWER ABSORPTION ANALYSIS OF REGENCIES AND CITIES IN SOUTH SUMATRA, INDONESIA
}

\author{
Eva Novaria*, Taufiq Marwa, Didik Susetyo, Azwardi \\ Faculty of Economics, University of Sriwijaya, Indonesia \\ *E-mail: eva.novaria@gmail.com
}

\begin{abstract}
The economic growth is necessary to increase prosperity and regional economic performance. For major component of economic growth on the demand side is the value of investment and government expenditure. Therefore, investment and government expenditure has a strategic role in improving the performance of regional economy. In line with that matter, this study was aimed to determine the relationship of government expenditure simultaneously with the economic performance of the regencies/cities in South Sumatra province. The data used is secondary data obtained from the Central Statistics Agency (BPS) of regencies/cities in the province of South Sumatra, Bank Indonesia, and the General Director of Fiscal Balance (DJPK) of Indonesia Republic. The analytical method used was multiple regression panel data using simultaneous equations. The results showed: government expenditure, investment and labor altogether significantly affects economic growth; the variables of economic growth, fiscal capacity, general allocation funds and the number of labor altogether affect government expenditure; and the variables of economic growth, government expenditure, wages and the number of investment altogether affect employment. This study has a limitation in a variety of variables that affect government expenditure, because it is for more research needs to re-inventory the variables that affect government expenditure, including variable Special Allocation Fund (DAK).
\end{abstract}

\section{KEY WORDS}

Government expenditure, economic growth, labor absorption.

Local government efforts to boost economic growth through policies including expenditures for purchasing of goods and services that will drive the increasing demand in the economy. Empirical studies of relationship between government expenditure on economic growth show different results, it was revealed from the study Purbadharmaja (2006) and Sodik (2007) which shows the government expenditure contributed to a real and positive impact on economic growth.

In 2001-2005, economic growth in South Sumatra achieved 5.36 percent, and slightly contracted in 2006-2010, with an average growth of 7.08 percent as the global economic crisis of 2008. The year 2011 shows the national economic recovery grew 7.6 percent and South Sumatera also grew but at a lower level that is equal to 5.9 per cent. This economic performance gives hope for the improvement of regional economies in the future.

The increasing of economic conditions also reflected on regional growth in capital expenditure. South Sumatra Province capital expenditure in 2000-2005 grew by 35.74 per cent, followed by Banten province grew by 29.95 percent, Jambi province grew by 17.19 percent, Bangka Belitung grew by 10.61 percent and Lampung grew 3.6 percent.

The increasing of economic growth and capital expenditure reflects the higher economic activity driven by the community and government, so it is expected to have impact to raise aggregate demand. Aggregate consumption in 2000-2009 grew at an average of 5.73 percent. Household consumption played a major role in accelerating the growth of aggregate consumption, contributing around 87 per cent, or 60.81 percent to the GDP of South Sumatra in 2009.

The number of local government expenditure depends on the reception area. The higher number of local reception, the higher tendency of local government will allocate the 
expenditure and vice-versa. Areas that have a high income tend to have high expenditure too. But the magnitude of expenditure allocation per sector remains highly dependent on local government policy which in this case is represented by the local government and the Regional Representatives Council.

Furthermore, when viewed from the side of expenditure or shopping areas, the average growth in shopping areas in 15 regencies/cities reached 31.04 percent, generally the average shopping areas from 2005-2009 the highest average growth rate shopping areas are East OKU regency, which reached 48.90 percent and the lowest was Palembang city with 19.85 percent.

However, when viewed from the level of local independence from 15 regencies/cities in South Sumatra Province from 2005-2009, as measured by the ratio of revenue (PAD) and sharing profit fund (DBH), towards regional expenditure, appeared that its development was still very small. In 2005-2009, the average of independence ratio was 0.41 or 41.00 percent. This figure showed that the average regional fiscal independence only contributed to regional expenditures was 41.00 percent. Meanwhile, if viewed by the average value of the contribution rate of the region's autonomy to regional expenditure in 2005-2009, the highest was Musi Banyuasin regency with 0.89 , or 89 percent, and the lowest was OKI regency with 0.24 or 24 percent. This showed that the level of fiscal independence Musi Banyuasin region was already quite high, while the degree of fiscal independence OKI was still very low.

Correspondingly, in order to reduce inequalities in the financing needs and the control of taxes between central and local governments had been handled by the financial balance between the central and regional governments, especially from General Allocation Fund (DAU) will provide certainty for the regions in obtaining financial sources to finance expenditure needs which are its responsibility.

Based on the description and objective conditions in the field of government expenditure in the context of the regional economy as well as some research results had been carried out earlier, then it is necessary to conduct a study related to the influence of local government expenditure on the performance of the regional economy in the regencies/cities of South Sumatra province. Indicators of economic performance in cities/regencies can be approximated by the condition of local fiscal capacity, the size of the GDP, and rising employment.

\section{LITERATURE REVIEW}

Regional Autonomy. Law No. 23 of 2014 regulate in detail about local government. The law authorizes very significantly to the regional administration. The authority of the central government were not transferred to the local government is foreign policy, defense, security, justice, monetary, national fiscal, and religion (Article 10, paragraph 3).

The regional autonomy policy is intended in order to accelerate the improvement of public welfare. However, in this case a lot of research has focused on regional autonomy with the results vary varied.

Fiscal Decentralization. In the implementation of fiscal decentralization, based on Law No. 33 of 2004, the income area in the implementation of decentralization consists of local revenue and financing. It was also stated in article 5 of Law No. 33 of 2004 that the local revenue comes from revenue (PAD), balance funds, and other local revenue legitimate. While the financial sources of the substantial number of local budgets, loan of region, regional reserve fund, and the separated sale of the wealth of areas. The magnitude of the reception area will determine government expenditure.

Zhang and Zou (1996) conducted research in China and discovered the phenomenon that the income derived from the fiscal and then used for the purposes of local government expenditure has yet managed to boost economic growth. The inability to increase economic growth means that do not affect the level of welfare. In addition, they found that fiscal decentralization was regarded as one of the threats to national macroeconomic stability.

Rodriguez-Pose and Kroijer (2009) conducted a study on the relationship between the level and form of fiscal decentralization and economic performance in Eastern Europe and 
Central Europe by using regression model. The result was that fiscal decentralization is negatively correlated with economic growth rates, local government, and local taxes.

Local Revenue. Local revenues consist of local taxes, levies, separated local wealth management results and other legitimate income areas. By legislation local revenues are earned by local regulations in accordance with the legislation. The purpose of the local revenue was to give authority to local governments to fund the implementation of regional autonomy in accordance with the potential of the area as the embodiment of decentralization.

Fiscal policy through an increase in the tax rate will have an impact on the business world, which in turn affects the employment absorption or unemployment. Less mobile labor, which is usually the unskilled workers, will be affected by the increase in tax rates.

Balance Fund. Balance fund is a component of the reception area which is quite large. The balancing fund consists of revenue-sharing, the general allocation fund, and special allocation funds. According to Law No. 33 of 2004, Balance Fund is aimed at reducing the fiscal gap between government and local government. The size of the funding balance of the budget is set annually in the State Budget.

Sharing revenue was comprised of sharing-revenue tax, sharing profit fund no-tax allocation fund general and special allocation funds. This sharing revenue funds consist of funds sharing sourced from taxes and natural resources. General Allocation Fund (DAU) has an understanding as funds from the state revenue-expenditure budget (APBN) allocated to a particular region with the aim to help fund special activities of local affairs in accordance with national priorities. Special Allocation Fund (DAK) is a fund sourced from APBN allocated to a certain region with the aim to help fund special activities of regional affairs and in accordance with national priorities.

Construction Model about Development of Government Expenditure:

Wagner Law. Wagner's Law is a law linking government expenditure to gross domestic product growth, known as "The Law of Expanding State Expenditure". In principle, it says that in the long term there is a tendency of the public sector will grow relative to national income. The development of government expenditure will be greater as a percentage of Gross National Product (GNP). Mangkusubroto (2013) says that in an economy where income per capita increased in relative terms, the government expenditure will also increase. Wagner's Law is formulated as follows:

$$
\frac{P_{k} P P_{1}}{P P K_{1}}<\frac{P_{k} P P_{2}}{P P K_{1}}<\ldots \frac{P_{k} P P_{n}}{P P K_{n}}
$$

Description: $P K P P=$ Government expenditures per capita; $P P K=$ Income per capita; 1,2, ..., $n=$ Duration (years).

Peacock and Wisman Theory. Peacock and Wisman (1961) say about the development of public expenditure based on the view that the government is constantly trying to increase expenditure while people do not like to pay taxes to finance growing government expenditure. Peacock and Wiseman stated that people have a tolerance level of the tax or the level of people's willingness to pay taxes. The tolerance level of this tax is an obstacle for the government to raise the tax levy arbitrarily.

Government expenditure is a policy of the government to finance the local construction included in the cost of the regional administration. In other words, local government expenditure is expenditure that is used to finance development in various fields, including in this case is the social, economic, governance, culture, order, tranquility, and so that is the task of government in general.

Economic Growth. Economic growth generally has terms of increasing output of goods and services in a certain area and is usually measured by the growth of the value of Gross Domestic Product (GDP). In this case there are three major factors or components that are important in the economic growth of a country or region (Todaro and Smith, 2006). The first is how much the level of capital accumulation that covers all forms or types of new investments to be allocated in the economy. The second is how large the population growth rate will increase the number of labor generation and the third is the level of technology 
advance that will directly influence the production process and ultimately will increase the quantity of production. Almost the same as Todaro and Smith (2006), Romer (2001) suggested that growth theory, Solow model focuses on four variables, namely: output $(Y)$, capital $(\mathrm{K})$, labor $(\mathrm{L})$ and Knowledge or the effectiveness of labor (A ), its growth model formulation is as follows:

$$
\mathrm{Yt}=\mathrm{F}(\mathrm{Kt}, \mathrm{At}, \mathrm{Lt})
$$

This formula shows that the dominant factor in the capital increases economic growth. In addition to these factors, the factors of labor and knowledge possessed such workers are also a determining factor of economic growth.

\section{METHODS OF RESEARCH}

This study discusses the causal relationship between government expenditure and economic performance of regencies/cities in the province of South Sumatra. The scope of this study was the regencies/cities which just become new regencies/cities in 2001. The type of data in this research is secondary data. The source of secondary data was taken from Central Statistics Agency (BPS) of regencies/cities in the province of South Sumatra, Bank Indonesia, and the Director General of Fiscal Balance (DJPK) Republic of Indonesia.

Causal relationship between government expenditure and regional economic performance was analyzed using simultaneous equations, which consists of three structural equations for each sector of the economy. Three equations/structural functions are: (1) a function of economic growth (PE) for each sector, (2) the function of shopping (BLJ) for each sector, and the function of the number of people working (TK) for each sector of the economy.

Function of Economy Growth:

$$
P E_{t i}=b_{0}+b_{1} T K_{t i}+b_{2} I N V_{t i}+b_{3} I N V_{t-11}+b_{4} I N V_{t-2 i}+b_{5} B L J_{t i}+b_{6} B L J_{t-1 i}+b_{7} B L J_{t-2 i}+b_{i} D_{i}+w_{1}
$$

where: PE: economic growth; TK: the number of labor; INV: investment; BLJ: Shopping; D: dummy region; and $\mathrm{t}$ : year $\mathrm{t}$; $\mathrm{i}$ : sector (agriculture, trade sector, industrial sector and the construction sector).

Function of Government Expenditure (Expenditure):

$$
B L J_{t i}=c_{0}+c_{1} P E_{t i}+c_{2} K A F I S_{t i}+c_{3} D A U_{t i}+c_{4} T K_{t i}+c_{i} D_{i}+w_{2}
$$

where: BLJ: government expenditure; PE: economic growth; TK: the number of labor; KAFIS: fiscal capacity; DAU: General Allocation Funds; D: Area (REGENCIES/city); t: t year; and i: sector (agriculture, trade sector, industrial sector and the construction sector).

Functions of Labor:

$$
\mathrm{K}_{\mathrm{ti}}=\mathrm{d}_{0}+\mathrm{d}_{1} P E_{\mathrm{ti}}+\mathrm{d}_{2} U P A H_{\mathrm{ti}}+\mathrm{d}_{3} B L J_{\mathrm{ti}}+\mathrm{d}_{4} I N V_{\mathrm{ti}}+\mathrm{d}_{\mathrm{i}} \mathrm{D}_{\mathrm{i}}+\mathrm{w}_{3}
$$

where: BLJ: government expenditure; PE: economic growth; TK: the number of labor; INV: investment; UPAH: the wage rate; $\mathrm{D}$ : area (REGENCIES/city); t: $t$ year; and I: sectors (agriculture, trade sector, industrial sector and the construction sector).

\section{RESULTS AND DISCUSSION}

Effect of Government Expenditure, Investment and Labor to Economic Growth of Agricultural Sector. Government expenditure agriculture in the previous year determines the relative growth rate of the agricultural sector current year (year $\mathrm{t}$ ). Private investment variable in the previous 2 years (lag-2) determined the relative growth rate of the agricultural sector current year (year t). This condition is due to investments in the agricultural sector needs 
time to produce output, so investments need time to make an impact on economic growth in the agricultural sector. The number of labor variable in the agricultural sector statistically was not significant affecting the economic growth of the agricultural sector, and the correlation was negative. This is due to the investments made in the regencies/cities in South Sumatra was capital intensive, where the investment made by the investor is investing infrastructure development using the modern tools of production and use of labor that have this level of expertise (skills), While the agricultural sector itself tends to be labor intensive with a workforce that has a relatively low skill. So the effect of increasing investment and employment in the agricultural sector is relatively less to economic growth. Judging from the regions variable, the majority of the regencies/cities in South Sumatera statistically was significant difference with Palembang, meaning that there are differences in average growth in agriculture between Palembang with most of the regencies/cities in the province of South Sumatra.

Table 1 - Effect of Government Expenditure, Investment and Labor to Economic Growth of Agricultural Sector

\begin{tabular}{|c|c|c|c|c|c|c|}
\hline \multirow{2}{*}{$\mathrm{n} / \mathrm{n}$} & \multicolumn{3}{|c|}{ Un-standardized Coefficients } & \multirow{2}{*}{ Beta } & \multirow{2}{*}{$\mathrm{T}$} & \multirow{2}{*}{ Sig. } \\
\hline & Beta & & Std. Error & & & \\
\hline (Constant) & 16,69521 & & 5,329757 & - & 3,132452 & 0,002132 \\
\hline Inblj_pert & 0,250211 & & 0,839762 & 0,159012 & 0,297955 & 0,766202 \\
\hline Inblj_pert_1 & 0,099855 & & 0,48282 & 0,065843 & 0,206816 & 0,83647 \\
\hline Inblj_pert_2 & $-0,13202$ & & 0,298136 & $-0,0876$ & $-0,44281$ & 0,658624 \\
\hline Ininv_pert & 0,300257 & & 0,235822 & 0,452512 & 1,273238 & 0,205154 \\
\hline Ininv_pert_1 & $-0,20859$ & & 0,303588 & $-0,32083$ & $-0,68709$ & 0,493221 \\
\hline Ininv_pert_2 & 0,66963 & & 0,420733 & 1,033587 & 1,591579 & 0,113853 \\
\hline Intk_pert & $-1,7241$ & & 1,197049 & $-1,30866$ & $-1,44029$ & 0,152135 \\
\hline lahat & 4,012734 & & 1,477318 & 0,667705 & 2,716228 & 0,007481 \\
\hline muba & 4,428758 & & 1,297514 & 0,73693 & 3,413264 & 0,000851 \\
\hline mura & 4,508074 & & 1,306436 & 0,750128 & 3,450666 & 0,00075 \\
\hline $\mathrm{me}$ & 3,128869 & & 0,974985 & 0,520633 & 3,209144 & 0,001669 \\
\hline oki & 4,55241 & & 1,78795 & 0,757505 & 2,546162 & 0,012031 \\
\hline oku & 3,207265 & & 1,109495 & 0,533678 & 2,890743 & 0,00449 \\
\hline prabu & $-0,49967$ & & 1,641401 & $-0,08314$ & $-0,30441$ & 0,761288 \\
\hline pgalam & 1,347134 & & 1,300526 & 0,224158 & 1,035838 & 0,302158 \\
\hline$\| \mathrm{lg}$ & $-1,09279$ & & 1,563149 & $-0,18184$ & $\begin{array}{l}-0,6991 \\
\end{array}$ & 0,485713 \\
\hline byasin & 5,410015 & & 1,814931 & 0,900208 & 2,980838 & 0,003419 \\
\hline oi & 6,636947 & & 3,068432 & 1,104365 & 2,162977 & 0,032331 \\
\hline okut & 4,653295 & & 1,762176 & 0,774292 & 2,640654 & 0,009265 \\
\hline okus & 7,181182 & & 3,166708 & 1,194924 & 2,267712 & 0,024959 \\
\hline- & Sum of Squares & Df & Mean Square & $\mathrm{F}$ & Sig. & \\
\hline Regression & 249,1699 & 20 & 12,4585 & 6,289613 & 0,000 & \\
\hline Residual & 263,4471 & 133 & 1,980805 & - & - & \\
\hline Total & 512,617 & 153 & - & - & - & \\
\hline
\end{tabular}

Affect of Government Expenditure, Investment and Labor to Economic Growth Sector Trade. Government expenditure in two years ago relatively determines the growth rate of trade sector current year (year t). This reinforces the notion that there is a part of government expenditure that affect for a medium/long term.

Private investment variable in the previous 2 years (lag-2) relatively determined the growth rate of the trade sector current year (year $\mathrm{t}$ ). This condition is caused by investment in the trade sector takes to produce output, so investments need time to make an impact on economic growth in the trade sector. Number of workers variable in the trade sector statistically was not significant affect the economic growth of the trade sector, and the correlation was negative. This is because investments in the trade sector in the regencies/cities in South Sumatra is large trade, where investment was made by investors is 
investment of infrastructure construction trade, so that workers absorbed not too many and most have a level of expertise (skills), While the trade sector in South Sumatera classified as medium and small trade, thus increasing employment in the sector of commerce of micro, small and medium enterprises had little impact on economic growth in the trade sector. Judging from the regions variable, the majority of the regencies/cities in South Sumatra was statistically and significantly different with the city of Palembang, which means that there are differences in the average growth of trade between Palembang and with most of the regencies/cities in the province of South Sumatra. Most Regencies/cities have an average growth rate below the city of Palembang.

Table 2 - Effect of Government Expenditure, Investment, and Labor,

Trade Sector to Economic Growth

\begin{tabular}{|c|c|c|c|c|c|c|}
\hline \multirow{2}{*}{$n / n$} & \multicolumn{3}{|c|}{ Unstandardized Coefficients } & \multirow{2}{*}{ Beta } & \multirow{2}{*}{$\mathrm{t}$} & \multirow{2}{*}{ Sig. } \\
\hline & \multicolumn{2}{|l|}{ Beta } & Std. Error & & & \\
\hline (Constant) & \multicolumn{2}{|l|}{3,187649} & 5,514785 & - & 0,578019 & 0,564229 \\
\hline Inblj_dagt & \multicolumn{2}{|l|}{1,714617} & 1,890368 & 1,242993 & 0,907028 & 0,366032 \\
\hline Inblj_dagt_1 & \multicolumn{2}{|l|}{$-0,7572$} & 1,195789 & $-0,5545$ & $-0,63322$ & 0,527676 \\
\hline Inblj_dagt_2 & \multicolumn{2}{|l|}{0,155362} & 0,289811 & 0,115696 & 0,536082 & 0,592797 \\
\hline Ininv_dagt & \multicolumn{2}{|l|}{0,043196} & 0,310525 & 0,049981 & 0,139108 & 0,889575 \\
\hline Ininv_dagt_1 & \multicolumn{2}{|l|}{$-0,03423$} & 0,318207 & $-0,03818$ & $-0,10757$ & 0,914502 \\
\hline Ininv_dagt_2 & \multicolumn{2}{|l|}{0,024748} & 0,25209 & 0,026908 & 0,098172 & 0,921943 \\
\hline Intk_dagt & \multicolumn{2}{|l|}{$-0,25406$} & 1,625554 & $-0,15289$ & $-0,15629$ & 0,876043 \\
\hline lahat & \multicolumn{2}{|l|}{$-2,07126$} & 1,671222 & $-0,4033$ & $-1,23937$ & 0,217392 \\
\hline muba & \multicolumn{2}{|l|}{$-0,99885$} & 0,604906 & $-0,19449$ & $\begin{array}{l}-1,65124 \\
\end{array}$ & 0,101048 \\
\hline mura & \multicolumn{2}{|l|}{$-2,03234$} & 2,258426 & $-0,39573$ & $\begin{array}{l}-0,89989 \\
\end{array}$ & 0,369804 \\
\hline me & \multicolumn{2}{|l|}{$-0,31529$} & 0,649731 & $-0,06139$ & $-0,48526$ & 0,628287 \\
\hline oki & \multicolumn{2}{|l|}{$-0,91161$} & 0,673148 & $-0,1775$ & $\begin{array}{l}-1,35425 \\
\end{array}$ & 0,177954 \\
\hline oku & \multicolumn{2}{|l|}{$-0,95028$} & 0,994528 & $-0,18503$ & $-0,95551$ & 0,341054 \\
\hline prabu & \multicolumn{2}{|l|}{0,339726} & 1,099291 & 0,066149 & 0,309041 & 0,757774 \\
\hline pgalam & \multicolumn{2}{|l|}{$-2,21249$} & 2,406191 & $-0,4308$ & $-0,9195$ & 0,3595 \\
\hline$\| \mathrm{gg}$ & \multicolumn{2}{|l|}{$-2,96855$} & 2,168568 & $-0,57802$ & $-1,3689$ & 0,173338 \\
\hline byasin & \multicolumn{2}{|l|}{$-0,41369$} & 0,796742 & $-0,08055$ & $-0,51923$ & 0,604461 \\
\hline oi & \multicolumn{2}{|l|}{$-0,47077$} & 1,337199 & $-0,09167$ & $-0,35206$ & 0,725351 \\
\hline okut & \multicolumn{2}{|l|}{$-0,07942$} & 0,769992 & $-0,01546$ & $-0,10314$ & 0,918007 \\
\hline okus & \multicolumn{2}{|l|}{$-0,61381$} & 1,053398 & $-0,11952$ & $-0,5827$ & 0,561085 \\
\hline 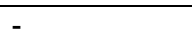 & Sum of Squares & Df & Mean Square & $\mathrm{F}$ & Sig. & \\
\hline Regression & 164,210 & 20 & 8,210529 & 6,984628 & 0,000 & \\
\hline Residual & 156,343 & 133 & 1,175514 & - & - & \\
\hline Total & 320,553 & 153 & - & - & - & \\
\hline
\end{tabular}

Effect of Government Expenditure, Investment and Labor to Economic Growth Industrial Sector. Government expenditure two years earlier relative growth rate of the industrial sector determines current year (year $\mathrm{t}$ ). This reinforces the notion that there is a part of government expenditure that affect for a medium/long term.

Private investment variable one year earlier (lag-1) determined the relative growth rate of the industrial sector current year (year $\mathrm{t}$ ). This condition was caused by the investment in the industrial sector takes to produce output, so investments need time to make an impact on economic growth in the industrial sector. No significant effect of the number of workers the industrial sector to the economic growth of industrial sector in them due to the investments made in the regencies/cities in South Sumatra for the industrial sector is capital-intensive, where the investment was made by the investor is investing infrastructure development industries that use modern production equipment and the use of labor that have such a level of expertise (skills).

On the other hand, the rapidly growing sector of small industries in South Sumatra While that tends to be labor-intensive with a workforce that has a relatively low skill. So the 
effect of increasing investment and employment in the industrial sector was relatively less to economic growth in the industrial sector. Judging from regions variable, the majority of the regencies/cities in South Sumatera was statistically and significantly different with the city of Palembang, which means that there are differences in the average growth in the industrial sector between Palembang with most of the regencies/cities in the province of South Sumatra. Most regencies/cities have an average growth rate of the industrial sector below the city of Palembang.

Table 3 - Results of Estimation Model Effects of Government Expenditure, Investing, and Labor to Economic Growth Industrial Sector

\begin{tabular}{|c|c|c|c|c|c|c|}
\hline \multirow{2}{*}{$n / n$} & \multicolumn{3}{|c|}{ Unstandardized Coefficients } & \multirow{2}{*}{ Beta } & \multirow{2}{*}{$\mathrm{t}$} & \multirow{2}{*}{ Sig. } \\
\hline & \multicolumn{2}{|c|}{ Beta } & Std. Error & & & \\
\hline (Constant) & \multicolumn{2}{|l|}{5,149959} & 17,21899 & - & 0,299086 & 0,765348 \\
\hline Inblj_indt & \multicolumn{2}{|l|}{3,130253} & 3,670778 & 1,62244 & 0,852749 & 0,395355 \\
\hline Inblj_indt_1 & \multirow{2}{*}{\multicolumn{2}{|c|}{$\begin{array}{l}-2,33003 \\
0,023616\end{array}$}} & 2,743128 & $-1,2195$ & $-0,84941$ & 0,397204 \\
\hline Inblj_indt_2 & & & 0,38303 & 0,012207 & 0,061655 & 0,950932 \\
\hline Ininv_indt & \multicolumn{2}{|l|}{$-0,35237$} & 0,594137 & $-0,53887$ & $-0,59309$ & 0,554146 \\
\hline Ininv_indt_1 & \multicolumn{2}{|l|}{0,766724} & 0,84458 & 1,177943 & 0,907817 & 0,365642 \\
\hline Ininv_indt_2 & \multicolumn{2}{|l|}{$-0,21299$} & 0,321008 & $-0,32952$ & $-0,66349$ & 0,50818 \\
\hline Intk_indt & \multicolumn{2}{|l|}{$-0,14889$} & 1,088907 & $-0,12157$ & $-0,13674$ & 0,891449 \\
\hline lahat & \multicolumn{2}{|l|}{$-2,82992$} & 1,392254 & $-0,40921$ & $-2,03261$ & 0,044112 \\
\hline muba & \multicolumn{2}{|l|}{$-1,90184$} & 1,321884 & $-0,27501$ & $-1,43874$ & 0,15261 \\
\hline mura & \multirow{2}{*}{\multicolumn{2}{|c|}{$\begin{array}{c}-1,95778 \\
0,146328\end{array}$}} & 0,982767 & $-0,27088$ & $-1,99211$ & 0,048438 \\
\hline $\mathrm{me}$ & & & 2,430469 & 0,021159 & 0,060206 & 0,952084 \\
\hline oki & \multicolumn{2}{|l|}{$-1,2256$} & 1,896056 & $-0,17722$ & $-0,64639$ & 0,519155 \\
\hline oku & \multicolumn{2}{|l|}{$-0,58001$} & 1,358846 & $-0,08025$ & $-0,42684$ & 0,670195 \\
\hline prabu & \multicolumn{2}{|l|}{$-2,42551$} & 1,065515 & $-0,35073$ & $-2,27638$ & 0,024446 \\
\hline pgalam & \multicolumn{2}{|l|}{$-4,7423$} & 2,049264 & $-0,68575$ & $-2,31415$ & 0,022216 \\
\hline Ilg & \multicolumn{2}{|l|}{$-4,08917$} & 2,70769 & $-0,5913$ & $-1,5102$ & 0,1334 \\
\hline byasin & \multicolumn{2}{|l|}{$\begin{array}{l}-0,92131 \\
-084731\end{array}$} & 1,060212 & $-0,13322$ & $-0,86898$ & 0,386445 \\
\hline oi & \multicolumn{2}{|l|}{$-0,84731$} & 2,34641 & $-0,12252$ & $-0,36111$ & 0,718598 \\
\hline okut & \multicolumn{2}{|l|}{$-2,3623$} & 0,887265 & $-0,34159$ & $-2,66245$ & 0,00873 \\
\hline okus & \multicolumn{2}{|l|}{$-1,06557$} & 2,571147 & $-0,15408$ & $-0,41443$ & 0,679235 \\
\hline & Sum of Squares & df & Mean Square & $\mathrm{F}$ & Sig. & \\
\hline Regression & 407,026 & 20 & 20,35131 & 8,51018 & 0,000 & \\
\hline Residual & 313,274 & 131 & 2,391406 & - & - & \\
\hline Total & 720,300 & 151 & - & - & - & \\
\hline
\end{tabular}

Effect of Government Expenditure, Investment and Labor towards Economic Growth of Sector Construction. Previous year government expenditure variable was relatively defined growth rate of the construction sector in the current year (year t). This condition makes the presumption that there is a part of government expenditure affects for a medium/long term becomes stronger.

Private investment variable in the previous 2 years (lag-2) was relative determined growth rate of the construction sector in the current year (year t). This condition is due to investments in the construction sector takes time to ensure their completion (become investment) needs time to make an impact on economic growth in the construction sector. The number of labor variable in the agricultural sector was not statistically and significantly affect the economic growth of the agricultural sector, this is caused by the construction sector is in the process of construction requires a lot of manpower.

Judging from regions variable, the majority of the regencies/cities in South Sumatra was not significantly and statistically different in Palembang, meaning that there is no difference in the average growth of the construction sector between Palembang and with most of the regencies/cities in the province of South Sumatra. This is somewhat understandable because each regency/city has a budget which was allocated for the construction sector, especially under the departments PU Bina Marga and PU Cipta Karya. 
Table 4 - Results of Estimation Model Effects of Government Expenditure, Investing, Labor and Economic Growth of Construction Sector

\begin{tabular}{|c|c|c|c|c|c|c|}
\hline \multirow{2}{*}{$\mathrm{n} / \mathrm{n}$} & \multicolumn{3}{|c|}{ Unstandardized Coefficients } & \multirow[b]{2}{*}{ Beta } & \multirow[b]{2}{*}{$t$} & \multirow[b]{2}{*}{ Sig. } \\
\hline & Beta & & Std. Error & & & \\
\hline (Constant) & 18,971 & 11,16 & & - & 1,699 & 0,092 \\
\hline Inblj_konst & 0,191 & 1,099 & & 0,142 & 0,174 & 0,862 \\
\hline Inblj_konst_1 & 0,042 & 0,609 & & 0,034 & 0,069 & 0,945 \\
\hline Inblj_konst_2 & $-0,308$ & 0,549 & & $-0,265$ & $-0,561$ & 0,576 \\
\hline Ininv_konst & $-0,649$ & 0,619 & & $-0,916$ & $-1,049$ & 0,296 \\
\hline llinv_konst_1 & $-0,282$ & 0,362 & & $-0,396$ & $-0,778$ & 0,438 \\
\hline Ininv_konst_2 & 0,481 & 0,317 & & 0,707 & 1,520 & 0,131 \\
\hline Intk_konst & 2,000 & 1,629 & & 1,505 & 1,228 & 0,222 \\
\hline lahat & $-0,800$ & 1,351 & & $-0,182$ & $-0,592$ & 0,555 \\
\hline muba & 0,885 & 1,650 & & 0,201 & 0,537 & 0,592 \\
\hline mura & 0,281 & 1,272 & & 0,064 & 0,221 & 0,825 \\
\hline me & 0,796 & 0,890 & & 0,181 & 0,894 & 0,373 \\
\hline oki & $-0,646$ & 2,203 & & $-0,147$ & $-0,293$ & 0,770 \\
\hline oku & 0,452 & 1,209 & & 0,103 & 0,374 & 0,709 \\
\hline prabu & 0,391 & 0,883 & & 0,089 & 0,443 & 0,659 \\
\hline pgalam & 0,663 & 0,985 & & 0,151 & 0,673 & 0,502 \\
\hline$\| \lg$ & 0,475 & 0,699 & & 0,108 & 0,680 & 0,498 \\
\hline byasin & $-0,591$ & 1,790 & & $-0,134$ & $-0,330$ & 0,742 \\
\hline oi & 0,011 & 0,991 & & 0,003 & 0,011 & 0,991 \\
\hline okut & $-1,170$ & 3,141 & & $-0,266$ & $-0,372$ & 0,710 \\
\hline okus & 0,149 & 1,251 & & 0,034 & 0,119 & 0,906 \\
\hline- & Sum of Squares & df & Mean Square & $\mathrm{F}$ & Sig, & \\
\hline Regression & 116,3309 & 20 & 5,816546 & 4,145959 & 0,000 & \\
\hline Residual & 186,5915 & 133 & 1,402944 & & - & \\
\hline Total & 302,9224 & 153 & - & - & - & \\
\hline
\end{tabular}

Effect of Economic Growth, Fiscal Capacity, General Allocation Fund and Labor towards the Agricultural Sector Government Expenditure. Economic growth variable of agricultural sector (PE) significantly affect the agricultural sector expenditures.

Table 5 - Effect of Economic Growth, Fiscal Capacity, General Allocation Fund and Labor of the Agricultural Sector Government Expenditure

\begin{tabular}{|c|c|c|c|c|c|c|}
\hline \multirow{2}{*}{$n / n$} & \multicolumn{3}{|c|}{ Unstandardized Coefficients } & \multirow{2}{*}{ Beta } & \multirow{2}{*}{$\mathrm{t}$} & \multirow{2}{*}{ Sig. } \\
\hline & \multicolumn{2}{|c|}{ Beta } & Std. Error & & & \\
\hline (Constant) & \multicolumn{2}{|l|}{$-14,45292022$} & 5,885156 & - & $-2,45583$ & 0,015317 \\
\hline Indau & \multicolumn{2}{|l|}{0,279286317} & 0,158807 & 0,295469 & 1,758647 & 0,080887 \\
\hline Inpe_pert & \multicolumn{2}{|l|}{0,954445415} & 0,274569 & 1,501852 & 3,47616 & 0,000683 \\
\hline Intk_pert & \multicolumn{2}{|l|}{$-0,569690659$} & 0,531599 & $-0,68043$ & $-1,07166$ & 0,285773 \\
\hline Inkafis & \multicolumn{2}{|l|}{0,51875742} & 0,149579 & 0,53108 & 3,468126 & 0,000702 \\
\hline lahat & \multicolumn{2}{|l|}{$-0,942632744$} & 0,622612 & $-0,24681$ & $-1,514$ & 0,132347 \\
\hline muba & \multicolumn{2}{|l|}{$-1,316968094$} & 0,832135 & $-0,34482$ & $-1,58264$ & 0,115827 \\
\hline mura & \multicolumn{2}{|l|}{$-1,643648485$} & 0,835705 & $-0,43036$ & $-1,96678$ & 0,051244 \\
\hline me & \multicolumn{2}{|l|}{$-1,067546737$} & 0,67413 & $-0,27952$ & $-1,58359$ & 0,115609 \\
\hline oki & \multicolumn{2}{|l|}{0,620072788} & 1,097924 & 0,162354 & 0,564768 & 0,573162 \\
\hline oku & \multicolumn{2}{|l|}{$-0,544802303$} & 0,680798 & $-0,14265$ & $-0,80024$ & 0,424967 \\
\hline prabu & \multicolumn{2}{|l|}{$-0,933573641$} & 1,086792 & $-0,24444$ & $-0,85902$ & 0,391842 \\
\hline pgalam & \multicolumn{2}{|l|}{0,103419036} & 0,615466 & 0,027078 & 0,168034 & 0,866806 \\
\hline $\mathrm{llg}$ & \multicolumn{2}{|l|}{$-0,412165446$} & 0,99455 & $-0,10792$ & $-0,41442$ & 0,679216 \\
\hline byasin & \multicolumn{2}{|l|}{$-1,151299069$} & 0,867191 & $-0,30145$ & $-1,32762$ & 0,186528 \\
\hline oi & \multicolumn{2}{|l|}{$-0,802038645$} & 0,564654 & $-0,21$ & $-1,42041$ & 0,157778 \\
\hline okut & \multicolumn{2}{|l|}{0,057212094} & 0,842397 & 0,01498 & 0,067916 & 0,945952 \\
\hline okus & \multicolumn{2}{|l|}{$-0,897912688$} & 0,669668 & $-0,2351$ & $-1,34083$ & 0,18221 \\
\hline- & Sum of Squares & $\mathrm{df}$ & Mean Square & $\mathrm{F}$ & Sig. & \\
\hline Regression & 123,8178 & 17 & 7,283399 & 7,681446 & 0,000 & \\
\hline Residual & 128,9526 & 136 & 0,948181 & - & - & \\
\hline Total & 252,7704 & 153 & - & - & - & \\
\hline
\end{tabular}


The high economic growth will stimulate an increase in economic activities that support the development, prompting the government to provide services in the form of facilities and infrastructure that support the evolving needs of society as a result of increased revenue.

Fiscal capacity variable (PAD $+\mathrm{DBH})$ significantly affect the agricultural sector of government expenditure. This condition is caused by the growing of freedom of government in regencies/cities in the era of regional autonomy in allocating revenue and revenue sharing on sectors that are the focus of each regencies/cities. General Allocation Fund variable (DAU) is also significant, due to the growing of freedom of government in regencies/cities in the era of regional autonomy in the allocation of DAU besides as an element of paying salaries.

Labor variable in the agricultural sector did not significantly affect the agricultural sector of government expenditure, because the pattern or formula in distributing government expenditure in the agricultural sector was relatively not accommodated by the number of labor. In addition, the pattern of government expenditure was not based on the number of workforce.

Judging from regions variable, the majority of the regencies/cities in South Sumatra was not significantly and statistically different in Palembang, meaning there is no difference in the average government expenditure agricultural sector in the city of Palembang.

Effect of Economic Growth, Fiscal Capacity, General Allocation Fund and Labor on Government Expenditure of Trade Sector. Variable economic growth trade (PE) has a positive relationship with the government expenditure of trade sector (according to theory). The high economic growth will stimulate an increase in economic activities that support development.

Table 6 - Effect of Economic Growth, Fiscal Capacity, General Allocation Fund and Labor on Government Expenditure of Trade Sector

\begin{tabular}{|c|c|c|c|c|c|}
\hline \multirow{2}{*}{$n / n$} & \multicolumn{3}{|c|}{ Unstandardized Coefficients } & \multirow{2}{*}{ Beta } & \multirow{2}{*}{$\mathrm{T}$} \\
\hline & \multicolumn{2}{|c|}{ Beta } & Std. Error & & \\
\hline (Constant) & \multicolumn{2}{|l|}{$-6,3538$} & 5,854516 & - & $-1,08528$ \\
\hline Indau & \multicolumn{2}{|l|}{0,14772} & 0,148441 & 0,160316 & 0,995142 \\
\hline Inpe_dag & \multicolumn{2}{|l|}{0,327395} & 0,521051 & 0,451617 & 0,628335 \\
\hline Intk_dagt & \multicolumn{2}{|l|}{2,273286} & 1,997508 & 1,887093 & 1,138061 \\
\hline Inkafis & \multicolumn{2}{|l|}{$-0,32928$} & 0,425499 & $-0,34581$ & $-0,77386$ \\
\hline lahat & \multicolumn{2}{|l|}{3,4004} & 1,92656 & 0,913327 & 1,765012 \\
\hline muba & \multicolumn{2}{|l|}{1,947684} & 1,56659 & 0,523136 & 1,243263 \\
\hline mura & \multicolumn{2}{|l|}{4,394674} & 2,831639 & 1,180383 & 1,551989 \\
\hline me & \multicolumn{2}{|l|}{1,354154} & 1,291793 & 0,363718 & 1,048275 \\
\hline oki & \multicolumn{2}{|l|}{1,032241} & 0,966897 & 0,277254 & 1,067582 \\
\hline oku & \multicolumn{2}{|l|}{2,340351} & 1,699574 & 0,628604 & 1,377022 \\
\hline prabu & \multicolumn{2}{|l|}{2,217643} & 2,527941 & 0,595646 & 0,877253 \\
\hline pgalam & \multicolumn{2}{|l|}{4,663475} & 2,813764 & 1,252581 & 1,657379 \\
\hline$\| \mathrm{lg}$ & \multicolumn{2}{|l|}{4,370136} & 2,026222 & 1,173792 & 2,156791 \\
\hline byasin & \multicolumn{2}{|l|}{1,312076} & 1,154039 & 0,352416 & 1,136943 \\
\hline oi & \multicolumn{2}{|l|}{3,09329} & 2,75408 & 0,830839 & 1,123166 \\
\hline okut & \multicolumn{2}{|l|}{0,642389} & 0,892369 & 0,172542 & 0,719869 \\
\hline okus & \multicolumn{2}{|l|}{2,253626} & 1,788197 & 0,60531 & 1,260279 \\
\hline - & Sum of Squares & $\mathrm{df}$ & Mean Square & $\mathrm{F}$ & Sig. \\
\hline Regression & 122,4839 & 17 & 7,204935 & 5,753293 & 0,000 \\
\hline Residual & 170,3148 & 136 & 1,252315 & - & - \\
\hline Total & 292,7987 & 153 & - & - & - \\
\hline
\end{tabular}

Fiscal capacity variable (PAD + DBH) positively associated with government expenditure trade, driven by the growing of freedom the government in regencies/cities in the era of regional autonomy in allocating revenue and revenue sharing on sectors that are the 
focus of each regencies/cities. Otherwise, the General Allocation Fund (DAU) variable has a directional relationship with government expenditure trade, driven by the growing of freedom of the government in regencies/cities in the era of regional autonomy in the allocation of DAU than as an element of paying salaries.

Workforce variable of trade sector has a directional relationship with government expenditure trade sector. This is somewhat understandable as more and more workers in the trade sector which largely utilize the facilities which were provided by government in regencies/cities. Judging from region variable, most of the regencies/cities in South Sumatra were not significantly different statistically in Palembang, meaning there was no difference in the average expenditure of the government sector trade between Palembang and with most of the regencies/cities in the province of South Sumatra.

Effect of Economic Growth, Fiscal Capacity, General Allocation Fund and Labor of the Government Expenditure of Industrial Sector. Economic growth variable of industrial sector $(\mathrm{PE})$ has a negative relationship with government expenditure. The high economic growth in the industrial sector did not increase government expenditure in this sector, due to the growth in the industrial sector largely supported by the growth of medium and large industrial sectors relatively did not require government facility.

Table 7 - Effect of Economic Growth, Fiscal Capacity, General Allocation Fund and Labor of the Government Expenditure of Industrial Sector

\begin{tabular}{|c|c|c|c|c|c|c|}
\hline \multirow{2}{*}{$\mathrm{n} / \mathrm{n}$} & \multicolumn{3}{|c|}{ Unstandardized Coefficients } & \multirow{2}{*}{ Beta } & \multirow{2}{*}{$\mathrm{T}$} & \multirow{2}{*}{ Sig. } \\
\hline & \multicolumn{2}{|l|}{ Beta } & Std. Error & & & \\
\hline (Constant) & \multicolumn{2}{|l|}{71,43585} & - & - & 1,064318 & 0,289099 \\
\hline Indau & \multicolumn{2}{|l|}{$-0,59588$} & 0,741025 & $-0,66812$ & $-0,80413$ & 0,422748 \\
\hline Inpe_ind & \multicolumn{2}{|l|}{$-2,13413$} & 2,391772 & $-4,11749$ & $-0,89228$ & 0,373842 \\
\hline Intk_indt & \multicolumn{2}{|l|}{3,058208} & 2,483466 & 4,817681 & 1,231428 & 0,22032 \\
\hline Inkafis & \multicolumn{2}{|l|}{$-0,25191$} & 0,711499 & $-0,27143$ & $-0,35405$ & 0,723858 \\
\hline lahat & \multicolumn{2}{|l|}{$-5,86827$} & 7,706659 & $-1,63717$ & $-0,76145$ & 0,447724 \\
\hline muba & \multicolumn{2}{|l|}{$-1,10107$} & 3,028699 & $-0,30718$ & $-0,36354$ & 0,716771 \\
\hline mura & \multicolumn{2}{|l|}{$-2,67396$} & 4,524607 & $-0,7138$ & $-0,59098$ & 0,555529 \\
\hline me & \multicolumn{2}{|l|}{$-5,74901$} & 5,304206 & $-1,6039$ & $-1,08386$ & 0,280374 \\
\hline oki & \multicolumn{2}{|l|}{$-8,49834$} & 9,194167 & $-2,37093$ & $-0,92432$ & 0,356982 \\
\hline oku & \multicolumn{2}{|l|}{$-2,93045$} & 3,974764 & $-0,78227$ & $-0,73726$ & 0,46225 \\
\hline prabu & \multicolumn{2}{|l|}{$-3,34425$} & 5,534242 & $-0,933$ & $-0,60428$ & 0,546677 \\
\hline pgalam & \multicolumn{2}{|l|}{$-4,35501$} & 8,649601 & $-1,21499$ & $-0,50349$ & 0,615445 \\
\hline $\mathrm{llg}$ & \multicolumn{2}{|l|}{$-1,48441$} & 5,283666 & $-0,41413$ & $-0,28094$ & 0,779187 \\
\hline byasin & \multicolumn{2}{|l|}{$-3,77005$} & 4,354255 & $-1,0518$ & $-0,86583$ & 0,38813 \\
\hline oi & \multicolumn{2}{|l|}{$-5,5872$} & 6,66462 & $-1,55876$ & $-0,83834$ & 0,403334 \\
\hline okut & \multicolumn{2}{|l|}{$-5,76367$} & 7,012032 & $-1,60799$ & $-0,82197$ & 0,412555 \\
\hline okus & \multicolumn{2}{|l|}{$-6,74204$} & 7,792315 & $-1,88095$ & $-0,86522$ & 0,388466 \\
\hline- & Sum of Squares & $\mathrm{df}$ & Mean Square & $\mathrm{F}$ & Sig. & \\
\hline Regression & 96,09551 & 17 & 5,652677 & 0,784834 & 0,007835 & \\
\hline Residual & 965,1193 & 134 & 7,202383 & - & - & \\
\hline Total & 1061,215 & 151 & - & - & - & \\
\hline
\end{tabular}

Fiscal capacity variable (PAD + DBH) was negatively related to the industrial sector of government expenditure, because the industrial sector largely supported by the growth of medium and large industrial sectors are relatively dint not require funding from government facilities. General Allocation Fund (DAU) variable has the opposite relationship (negative) with government expenditure the industrial sector, for the industrial sector largely supported by the growth of medium and large industrial sectors relatively did not require funding from government facilities.

Variable workforce of industrial sector has a unidirectional relationship with government expenditure the industrial sector. This is somewhat understandable as more and more workers in the industrial sector which largely utilize the facilities provided by the government 
in regencies/cities which is seen from regions variable, the majority of the regencies/cities in South Sumatera were not significantly and statistically different in Palembang.

Effect of Economic Growth, Fiscal Capacity, General Allocation Fund and Labor towards Government Expenditure of Construction Sector. The significant influence of the economic growth in the construction sector of the construction sector due to high economic growth will stimulate an increase in economic activities that support the development, prompting the government to provide services in the form of facilities and infrastructure that support the evolving the society needs/demands as a result of increased revenue.

Fiscal capacity variable has a positive relationship with government expenditure in the construction sector, driven by growing of freedom of regencies/cities in the era of regional autonomy in allocating revenue and revenue sharing on sectors that are the focus of each regencies/cities. General Allocation Fund (DAU) variable was significantly influenced which was caused by the growing of freedom of government in regencies/cities in the era of regional autonomy in the allocation of DAU beside as an element of pay salaries.

Workforce variable of construction sector has a directional relationship with government expenditure the construction sector, as more and more workers in the construction sector which largely utilize the facilities provided by the government in regencies/cities. Judging from the regions variable, the majority of the regencies/ cities in southern Sumatra was statistically and significantly difference with Palembang, meaning that there are differences in average government expenditure construction sector between Palembang and with most of the regencies/cities in the province of South Sumatra.

Table 8 - Effect of Economic Growth, Fiscal Capacity, General Allocation Fund and Labor towards Government Expenditure of Construction Sector

\begin{tabular}{|c|c|c|c|c|c|c|}
\hline \multirow{2}{*}{$n / n$} & \multicolumn{3}{|c|}{ Unstandardized Coefficients } & \multirow{2}{*}{ Beta } & \multirow{2}{*}{$\mathrm{t}$} & \multirow{2}{*}{ Sig. } \\
\hline & \multicolumn{2}{|l|}{ Beta } & Std. Error & & & \\
\hline (Constant) & \multicolumn{2}{|l|}{3,047312386} & - & - & 1,05273 & 0,294332 \\
\hline Indau & \multicolumn{2}{|l|}{0,271463843} & 0,073038 & 0,336022 & 3,716729 & 0,000294 \\
\hline Inpe_kons & \multicolumn{2}{|l|}{0,313121062} & 0,153439 & 0,422028 & 2,040685 & 0,043217 \\
\hline Intk_konst & \multicolumn{2}{|l|}{0,506491514} & 0,186439 & 0,513574 & 2,71666 & 0,007452 \\
\hline Inkafis & \multicolumn{2}{|l|}{0,074039516} & 0,103468 & 0,088686 & 0,715579 & 0,475478 \\
\hline lahat & \multicolumn{2}{|l|}{0,577182248} & 0,270684 & 0,176818 & 2,13231 & 0,034778 \\
\hline muba & \multicolumn{2}{|l|}{1,604596255} & 0,347685 & 0,491564 & 4,61509 & $8,99 \mathrm{E}-06$ \\
\hline mura & \multicolumn{2}{|l|}{1,449060259} & 0,338803 & 0,443916 & 4,276999 & $3,55 \mathrm{E}-05$ \\
\hline me & \multicolumn{2}{|l|}{1,033584858} & 0,288272 & 0,316636 & 3,585445 & 0,000468 \\
\hline oki & \multicolumn{2}{|l|}{1,648094918} & 0,338732 & 0,50489 & 4,865476 & $3,11 \mathrm{E}-06$ \\
\hline oku & \multicolumn{2}{|l|}{1,101675697} & 0,302944 & 0,337496 & 3,636567 & 0,000391 \\
\hline prabu & \multicolumn{2}{|l|}{0,687095178} & 0,295908 & 0,21049 & 2,321987 & 0,021719 \\
\hline pgalam & \multicolumn{2}{|l|}{1,231466158} & 0,318833 & 0,377257 & 3,862423 & 0,000173 \\
\hline$\| \mathrm{lg}$ & \multicolumn{2}{|l|}{0,516484282} & 0,270756 & 0,158224 & 1,907565 & 0,058556 \\
\hline byasin & \multicolumn{2}{|l|}{0,19493433} & 0,244962 & 0,059718 & 0,795774 & 0,42755 \\
\hline oi & \multicolumn{2}{|l|}{1,396714231} & 0,268446 & 0,42788 & 5,20296 & $7,06 \mathrm{E}-07$ \\
\hline okut & \multicolumn{2}{|l|}{0,92749926} & 0,273283 & 0,284137 & 3,393913 & 0,000903 \\
\hline okus & \multicolumn{2}{|l|}{1,496397793} & 0,285361 & 0,458418 & 5,243878 & 0,000006 \\
\hline- & Sum of Squares & df & Mean Square & $\mathrm{F}$ & Sig. & \\
\hline Regression & 84,30317 & 17 & 4,95901 & 17,42601 & 0,000 & \\
\hline Residual & 38,70223 & 136 & 0,284575 & - & - & \\
\hline Total & 123,0054 & 153 & & - & - & \\
\hline
\end{tabular}

Effect of Economic Growth, Government Expenditure, Wages and Total Investment towards the Number of Employment of Agriculture Sector. Economic growth in partial agricultural sector (PE) did not significantly affect the number of agricultural laborers, even the shape of its influence is negative (not in accordance with the theory). Economic growth in the agricultural sector was mainly supported by large plantation sub-sector which is not too much to absorb labor. 
Table 9 - Effect of Economic Growth, Government Expenditure, Wages and Total Investment to Total Employment Agriculture

\begin{tabular}{|c|c|c|c|c|c|c|}
\hline \multirow{2}{*}{$n / n$} & \multicolumn{3}{|c|}{ Unstandardized Coefficients } & \multirow{2}{*}{ Beta } & \multirow{2}{*}{$\mathrm{t}$} & \multirow{2}{*}{ Sig. } \\
\hline & \multicolumn{2}{|l|}{$\mathrm{B}$} & Std. Error & & & \\
\hline (Constant) & \multicolumn{2}{|l|}{7,114646} & 3,538477 & - & 2,010652 & 0,046339 \\
\hline Inpe_pert & \multicolumn{2}{|l|}{$-0,24415$} & 0,261755 & $-0,32166$ & $-0,93275$ & 0,352603 \\
\hline Inblj_pert & \multicolumn{2}{|l|}{0,227416} & 0,147312 & 0,190405 & 1,543768 & 0,124968 \\
\hline Ininv_pert & \multicolumn{2}{|l|}{0,163716} & 0,090205 & 0,325059 & 1,814943 & 0,071736 \\
\hline Inupah_pert & \multicolumn{2}{|l|}{$-0,00644$} & 0,0858 & $-0,00352$ & $-0,07501$ & 0,94032 \\
\hline lahat & \multicolumn{2}{|l|}{0,999592} & 0,653424 & 0,219129 & 1,529774 & 0,128395 \\
\hline muba & \multicolumn{2}{|l|}{1,339624} & 0,783092 & 0,293671 & 1,710687 & 0,089419 \\
\hline mura & \multicolumn{2}{|l|}{1,070608} & 0,838455 & 0,234697 & 1,276882 & 0,20382 \\
\hline me & \multicolumn{2}{|l|}{0,767545} & 0,633931 & 0,16826 & 1,210771 & 0,228083 \\
\hline oki & \multicolumn{2}{|l|}{1,644209} & 0,611895 & 0,360442 & 2,687076 & 0,008108 \\
\hline oku & \multicolumn{2}{|l|}{0,69821} & 0,606169 & 0,153061 & 1,151841 & 0,251407 \\
\hline prabu & \multicolumn{2}{|l|}{$-1,50291$} & 0,428435 & $-0,32947$ & $-3,50791$ & 0,000613 \\
\hline pgalam & \multicolumn{2}{|l|}{$-0,50087$} & 0,434931 & $-0,1098$ & $-1,15161$ & 0,251501 \\
\hline$\| \mathrm{lg}$ & \multicolumn{2}{|l|}{$-1,50962$} & 0,378087 & $-0,33094$ & $-3,99278$ & 0,000106 \\
\hline byasin & \multicolumn{2}{|l|}{1,610271} & 0,839292 & 0,353002 & 1,918606 & 0,05713 \\
\hline oi & \multicolumn{2}{|l|}{1,528336} & 0,857097 & 0,33504 & 1,783155 & 0,076792 \\
\hline okut & \multicolumn{2}{|l|}{$\begin{array}{l}1,277907 \\
1558636\end{array}$} & 0,719437 & 0,280141 & 1,77626 & 0,077926 \\
\hline okus & \multicolumn{2}{|l|}{1,558636} & 0,963984 & 0,341683 & 1,61687 & 0,108224 \\
\hline- & Sum of Squares & df & Mean Square & $\mathrm{F}$ & Sig. & \\
\hline Regression & 169,8827 & 17 & 9,993098 & 24,53534 & $2,88 \mathrm{E}-33$ & \\
\hline Residual & 55,392 & 136 & 0,407294 & - & - & \\
\hline Total & 225,2747 & 153 & - & - & - & \\
\hline
\end{tabular}

Expenditure variable of agricultural sector was not significant in affecting employment. Although it was not statistically significant but do positive direction in accordance with the theory. Government expenditure in agriculture primarily for expenditure facilities and infrastructure can lead to absorb employment. Investment variable of agricultural sector significantly affect employment agricultural sector. Agricultural sector investment mainly for facilities and infrastructure can lead to absorb employment. Wage variable of labor in the agricultural sector did not significantly affect agricultural labors, even the relationship is negative (not in accordance with the theory). These conditions were due to the wage system in the agricultural sector has a relatively basic standard, so that the relative wage rate was not a major consideration for the people working in the agricultural sector. In addition, workers in the agricultural sector were mostly family labor is relatively depended on the level of wages.

Judging from the regions variable, the majority of the regencies/cities in South Sumatra was statistically and significantly different with the city of Palembang, which means that there were differences in the average number of agricultural labors between Palembang and with most of the regencies/cities in the province of South Sumatra. The average number of agricultural laborers of regencies/cities in South Sumatera was higher than the city of Palembang.

Effect of Economic Growth, Government Expenditure, Wages and Total Investment towards Total Employment of Trade Sector. In partial, economic growth variable of trade sector (PE) did not significantly affect the number of labor trade, but the direction was a positive relationship. This indicates that the economic growth in the trade sector to encourage the increasing the number of employment. This condition which was caused by the growing ability of small, micro, medium and large businesses, in fostering capital to develop the business so that the demand of increasing the input production factors which were included an increase in the demand for labor. 
Expenditure variable of trade sector was not significant in affecting employment. Government expenditure of trade sector, especially for expenditure facilities and infrastructure can lead to greater trade of sector employment. Investment variable of trade sector partially did not significantly affect trade sector employment. Investment trade sector mainly for facilities and infrastructure can lead to greater employment absorption. Wage variable of trade sector was not significant in affecting the trade sector workforce, even the relationship is negative (not in accordance with the theory). This condition was caused by the wage system in the trade sector still relatively did not meet average minimum wage (UMR) which had been set up, most of the growing trade sector was small scale and informal, so that aspect of the relative wage was not through market mechanisms (supply and demand that determines the price).

Table 10 - Effect of Economic Growth, Government Expenditure, Wages and Total Investment towards Total Employment of Trade Sector

\begin{tabular}{|c|c|c|c|c|c|c|}
\hline \multirow{2}{*}{$n / n$} & \multicolumn{3}{|c|}{ Unstandardized Coefficients } & \multirow{2}{*}{ Beta } & \multirow{2}{*}{$\mathrm{T}$} & \multirow{2}{*}{ Sig. } \\
\hline & \multicolumn{2}{|l|}{$\mathrm{B}$} & Std. Error & & & \\
\hline (Constant) & \multicolumn{2}{|l|}{0,257367} & 2,00284 & - & 0,128501 & 0,897942 \\
\hline Inpe_dag & \multicolumn{2}{|l|}{0,392875} & 0,430824 & 0,65285 & 0,911915 & 0,363427 \\
\hline Inblj_dagt & \multicolumn{2}{|l|}{0,086036} & 0,297836 & 0,103644 & 0,288872 & 0,773119 \\
\hline Ininv_dagt & \multicolumn{2}{|l|}{0,008069} & 0,128155 & 0,015515 & 0,062963 & 0,949888 \\
\hline Inupah_dagt & \multicolumn{2}{|l|}{$-0,10322$} & 0,125223 & $-0,08337$ & $-0,82432$ & 0,411198 \\
\hline lahat & \multicolumn{2}{|l|}{$-0,28831$} & 0,735785 & $-0,09329$ & $-0,39185$ & 0,695785 \\
\hline muba & \multicolumn{2}{|l|}{0,236791} & 0,53917 & 0,076616 & 0,439176 & 0,661231 \\
\hline mura & \multicolumn{2}{|l|}{$-0,729$} & 0,66801 & $-0,23588$ & $-1,09131$ & 0,277067 \\
\hline $\mathrm{me}$ & \multicolumn{2}{|l|}{$-0,12998$} & 0,267917 & $-0,04206$ & $-0,48514$ & 0,62836 \\
\hline oki & \multicolumn{2}{|l|}{0,514986} & 0,508342 & 0,16663 & 1,01307 & 0,312826 \\
\hline oku & \multicolumn{2}{|l|}{$-0,2511$} & 0,492922 & $-0,08125$ & $-0,50942$ & 0,611285 \\
\hline prabu & \multicolumn{2}{|l|}{$-0,63985$} & 0,305509 & $-0,20703$ & $-2,09438$ & 0,038081 \\
\hline pgalam & \multicolumn{2}{|l|}{$-0,80279$} & 0,794622 & $-0,25975$ & $-1,01028$ & 0,314157 \\
\hline$\| \mathrm{lg}$ & \multicolumn{2}{|l|}{$-0,34346$} & 1,152142 & $-0,11113$ & $-0,29811$ & 0,766075 \\
\hline byasin & \multicolumn{2}{|l|}{0,033913} & 0,331985 & 0,010973 & 0,102151 & 0,918787 \\
\hline oi & \multicolumn{2}{|l|}{$-0,6447$} & 0,366293 & $-0,2086$ & $-1,76007$ & 0,080644 \\
\hline okut & \multicolumn{2}{|l|}{0,102701} & 0,301285 & 0,03323 & 0,340877 & 0,733722 \\
\hline okus & \multicolumn{2}{|l|}{$-0,34538$} & 0,357877 & $-0,11175$ & $-0,96508$ & 0,336217 \\
\hline- & Sum of Squares & Df & Mean Square & $\mathrm{F}$ & Sig. & \\
\hline Regression & 71,5575 & 17 & 4,209265 & 17,16278 & 0,000 & \\
\hline Residual & 33,35474 & 136 & 0,245255 & - & - & \\
\hline Total & 104,9122 & 153 & & - & - & \\
\hline
\end{tabular}

Judging from the regions variable, most of the regencies/cities in South Sumatra was not significantly and statistically different in Palembang, meaning there was no difference in the average number of workers of trade sectors between Palembang and with most of the regencies/cities in the province of South Sumatra.

Effect of Economic Growth, Government Expenditure, Wages and Total Investment towards Total Workers of Industrial Sector. In partial, economic growth of industrial sector (PE) did not significantly affect the industrial sector workforce. This indicated that the economic growth of the industrial sector encouraged the increasing of employment. Expenditure variable of industrial sector was not also partially significant in affecting employment. Although, it was not statistically significant but do positive direction in accordance with the theory. Government expenditure, especially for the industrial sector and infrastructure expenditure could encourage the increasing of employment sector.

Investment variable of industrial sector did not partially and significantly affect the employment of industrial sector. However, it was not significant but its relationship showed positive direction in accordance with the theory. Investment sector mainly for facilities and infrastructure can lead to increase employment absorption. Wage labor variable of the 
industrial sector did not significantly affect the industrial sector workforce, even the relationship was negative (not in accordance with the theory). This condition which was caused by the system of remuneration in the industrial sector still relatively did not meet average wage minimum (UMR) which had been set, and most of the industrial sectors that develop are small scale and informal, so that aspect of the relative wage was not through market mechanisms (supply and demand that determined the price).

Judging from the regions variable, there were seven regencies/cities which had average number of their employees statistically different from the city of Palembang, namely: OKUS, OI, BANYUASIN, OKI, MUARA ENIM, and LAHAT, and seven other regencies/cities were not different from Palembang.

Table 11 - Effect of Economic Growth, Government Expenditure, Wages and Total Investment towards Total Workers of Industrial Sector

\begin{tabular}{|c|c|c|c|c|c|c|}
\hline \multirow[b]{2}{*}{$\mathrm{n} / \mathrm{n}$} & \multicolumn{3}{|c|}{ Unstandardized Coefficients } & \multirow[b]{2}{*}{ Beta } & \multirow[b]{2}{*}{$\mathrm{t}$} & \multirow[b]{2}{*}{ Sig. } \\
\hline & \multicolumn{2}{|c|}{$\mathrm{B}$} & Std. Error & & & \\
\hline (Constant) & \multicolumn{2}{|l|}{$-20,5959$} & 5,940578 & - & $-3,46699$ & 0,000708 \\
\hline Inpe_ind & \multicolumn{2}{|l|}{0,907065} & 0,558611 & 1,110908 & 1,623787 & 0,106771 \\
\hline Inblj_indt & \multicolumn{2}{|l|}{0,286338} & 0,183282 & 0,181764 & 1,562278 & 0,120581 \\
\hline Ininv_indt & \multicolumn{2}{|l|}{$-0,00718$} & 0,224488 & $-0,01345$ & $-0,03198$ & 0,974534 \\
\hline Inupah_indt & \multicolumn{2}{|l|}{$-0,00573$} & 0,255345 & $-0,00252$ & $-0,02242$ & 0,982142 \\
\hline lahat & \multicolumn{2}{|l|}{2,597352} & 1,317414 & 0,459986 & 1,971554 & 0,05072 \\
\hline muba & \multicolumn{2}{|l|}{0,57324} & 0,866767 & 0,10152 & 0,661354 & 0,509521 \\
\hline mura & \multicolumn{2}{|l|}{1,289033} & 1,079225 & 0,218432 & 1,194406 & 0,234429 \\
\hline me & \multicolumn{2}{|l|}{2,075205} & 0,607611 & 0,367515 & 3,41535 & 0,000843 \\
\hline oki & \multicolumn{2}{|l|}{2,653401} & 0,955745 & 0,469912 & 2,776264 & 0,006286 \\
\hline oku & \multicolumn{2}{|l|}{1,319755} & 0,925588 & 0,223638 & 1,425856 & 0,156235 \\
\hline prabu & \multicolumn{2}{|l|}{1,522472} & 1,438917 & 0,269627 & 1,058068 & 0,291928 \\
\hline pgalam & \multicolumn{2}{|l|}{2,394165} & 2,549505 & 0,424002 & 0,939071 & 0,349384 \\
\hline$\| \mathrm{lg}$ & \multicolumn{2}{|l|}{1,071081} & 1,797524 & 0,189687 & 0,595865 & 0,552271 \\
\hline byasin & \multicolumn{2}{|l|}{1,517682} & 0,708743 & 0,268779 & 2,141372 & 0,034053 \\
\hline oi & \multicolumn{2}{|l|}{2,329221} & 0,936031 & 0,412501 & 2,4884 & 0,014058 \\
\hline okut & \multirow{2}{*}{\multicolumn{2}{|c|}{$\begin{array}{l}2,450222 \\
2,747589\end{array}$}} & 1,48889 & 0,43393 & 1,645671 & 0,102175 \\
\hline okus & & & 1,030401 & 0,486593 & 2,666524 & 0,008608 \\
\hline- & Sum of Squares & Df & Mean Square & $\mathrm{F}$ & Sig. & \\
\hline Regression & 246,3847 & 17 & 14,49322 & 15,14403 & 0,000 & \\
\hline Residual & 128,2414 & 134 & 0,957025 & - & - & \\
\hline Total & 374,6261 & 151 & & - & & \\
\hline
\end{tabular}

Effect of Economic Growth, Government Expenditure, Wages and Total Investment towards Total Employment of Construction Sector. In partial, economic growth of the construction sector (PE) significantly affect the number of workers of the construction sector, forms of influence was positive (according to theory). This is possible because of economic growth of the construction sector was directly related to employment. Most projects in the construction sector were absorbing many workers who did not require such formal education too. Expenditure variable of construction sector was partially not significant in affecting employment. Government expenditure was the construction sector, especially for facilities and infrastructure expenditure such as roads, bridges and other public facilities to encourage increased employment.

Variable investment significantly affected the employment absorption of construction sector. Investment construction sector was strongly associated with employment. All projects/activities of construction sector relatively required much labors, especially workers who were not formally educated. 
Table 12 - Effect of Economic Growth, Government Expenditure, Wages and Total Investment towards Total Employment of Construction Sector

\begin{tabular}{|c|c|c|c|c|c|c|}
\hline \multirow{2}{*}{$n / n$} & \multicolumn{3}{|c|}{ Unstandardized Coefficients } & \multirow{2}{*}{ Beta } & \multirow{2}{*}{$\mathrm{t}$} & \multirow{2}{*}{ Sig. } \\
\hline & $B$ & & Std. Error & & & \\
\hline (Constant) & $-8,58293$ & \multicolumn{2}{|c|}{1.855902} & - & $-4,62467$ & 8,64E-06 \\
\hline Inpe kons & 0,333217 & \multicolumn{2}{|c|}{0,132861} & \begin{tabular}{|l|}
0,442921 \\
\end{tabular} & 2,508005 & 0,013317 \\
\hline Inblj_konst & 0,127782 & \multicolumn{2}{|c|}{0,154119} & 0,12602 & 0,829113 & 0,408493 \\
\hline Ininv_konst & 0,331852 & \multicolumn{2}{|c|}{0,092491} & 0,622404 & 3,587924 & 0,000464 \\
\hline Inupah_konst & $-0,09386$ & \multicolumn{2}{|c|}{0,071617} & \begin{tabular}{|l|}
$-0,08611$ \\
\end{tabular} & $-1,31055$ & 0,192219 \\
\hline lahat & 0,621237 & \multicolumn{2}{|c|}{0,352477} & 0,18769 & 1,762489 & 0,080233 \\
\hline muba & $-0,10989$ & \multicolumn{2}{|c|}{0,478158} & $-0,0332$ & $-0,22982$ & 0,818575 \\
\hline mura & 0,084444 & \multicolumn{2}{|c|}{0,450171} & 0,025512 & 0,187581 & 0,851484 \\
\hline $\mathrm{me}$ & $-0,23901$ & \multicolumn{2}{|c|}{0,330386} & $-0,07221$ & $-0,72343$ & 0,47066 \\
\hline oki & 0,697826 & \multicolumn{2}{|c|}{0,458293} & 0,210829 & 1,522662 & 0,130165 \\
\hline oku & 0,07782 & \multicolumn{2}{|c|}{0,40967} & 0,023511 & 0,189958 & 0,849625 \\
\hline prabu & 0,140832 & \multicolumn{2}{|c|}{0,341019} & 0,042549 & 0,412973 & 0,680276 \\
\hline pgalam & $-0,11316$ & \multicolumn{2}{|c|}{0,349804} & \begin{tabular}{|l|}
$-0,03419$ \\
\end{tabular} & $-0,32349$ & 0,746819 \\
\hline$\| \mathrm{lg}$ & 0,051135 & \multicolumn{2}{|c|}{0,292764} & 0,015449 & 0,174661 & 0,861606 \\
\hline byasin & 0,624458 & \multicolumn{2}{|c|}{0,370628} & 0,188663 & 1,684864 & 0,094308 \\
\hline oi & 0,100646 & \multicolumn{2}{|c|}{0,383222} & \begin{tabular}{|l}
0,030407 \\
\end{tabular} & 0,26263 & 0,793233 \\
\hline okut & 1,244015 & \multicolumn{2}{|c|}{0,6422} & \begin{tabular}{|l|}
0,375846 \\
\end{tabular} & 1,937114 & 0,054805 \\
\hline okus & 0,194061 & \multicolumn{2}{|c|}{0,456182} & 0,05863 & 0,425402 & 0,671216 \\
\hline- & Sum of Squares & $\mathrm{df}$ & Mean Square & $\mathrm{F}$ & Sig. & \\
\hline Regression & 76,59221 & 17 & 4,505424 & 15,89123 & 0,000 & \\
\hline Residual & 38,55823 & 136 & 0,283516 & - & - & \\
\hline Total & 115,1504 & 153 & & & - & \\
\hline
\end{tabular}

Wage labor variable of the construction sector did not significantly affect the construction sector workforce, even the relationship was negative (not in accordance with the theory). It was caused by a system of remuneration in the construction sector (labor) relatively did not have a basic standard, and tend to be below the minimum wage average.

Judging from the regions variable, most of the regencies/cities in South Sumatra were not significantly and statistically different in Palembang, meaning that, there is no difference in the average number of workers of the construction sector between Palembang and with most of the regencies/cities in the province of South Sumatra.

\section{CONCLUSION AND SUGGESTION}

Expenditure government variable in the current year (year $t$ ), expenditure government in the last year (year $t_{1}$ ), government expenditure in the last two years (year $t_{2}$ ), investment in the current year (year $t$ ), investment in the last year (year $t_{1}$ ), investment in the last two years (year $t_{2}$ ), and the number of labors in the current year (year $t$ ) were significantly improve economic growth.

Economic growth variable in the year $t$, fiscal capacity in the year $t$, general allocation fund in the year $t$ and the number of labors in the year $t$ were significantly influence government expenditure.

Economic growth variable together in the year $t$, government expenditure/spending in the year $t$, the level of wage in the year $t$ and the number of investment in the year $t$ significantly affect the employment absorption.

This research had limitation in varied variable which influenced government spending/expenditure, thus, for furthermore research needs to re-inventoried variables which influenced the government expenditure, such as Special Allocation Fund (DAK). 


\section{REFERENCES}

1. Adams, S. 2006 . The Impact of Privatization on Economic Growth and Income Inequality in Sub-Saharan Africa. The Journal of Social, Political, and Economic Studies, 31 (3): 295-320.

2. Adisasmita, R. 2008. Pengembangan Wilayah. Edisi Pertama. Graha IImu, Yogyakarta.

3. Astuti, U.P. 2007. Dampak Kebijakan Desentralisasi Fiskal terhadap Kinerja Keuangan dan Perekonomian Daerah di Provinsi Bengkulu: Suatu pendekatan Ekonometrika, Doctoral Dissertation, Sekolah Pascasarjana, Institut Pertanian Bogor, Bogor.

4. Azwardi. 2007. The Impact of Fiscal Decentralization on Interregional Economic Performance In Indonesia. Paper for Panel Discussion, Universitas Indonesia, Depok.

5. Branson, W.H. and J.M. Litvack.1981. Macroeconomics. Harper and Row Publishers, New York.

6. Baltagi, B. H. 2011. Econometrics, Fifth Edition. Berlin: Springer.

7. Calderon, C. and L. Serven. 2004. The Effects of Infrastructure Development on Growth and Income Distribution. The World Bank, Paper WPS3400. The World Bank, Washington, D.C.

8. Capello, R. 2007. Regional Economics. Routledge Advanced Texts In Economics. Routerledge, New York.

9. Case. E. K. and C. R. Fair. 1999. Principles of Macroeconomics. Fifth Edition. Prentice Hall, Upper Saddle River, New Jersey.

10. Costa-i-Font, J. and E. Rodriguez-Oreggia. 2005. Is the Impact of Public Investment Neutral Across the Regional Income Distribution?: Evidence from Mexico. Economic Geography, 81(3):305-322.

11. Halim \& Abdullah. 2006. Studi atas Belanja Modal pada Anggaran Pemerintah Daerah dalam Hubungannya dengan Belanja Pemeliharaan dan Sumber Pendapatan. Jurnal Akuntansi Pemerintah, Vol.2, No.2 : 17-32.

12. Hasan, M.F. \& D.A. Purwanto. 2005. Kebijakan Investasi Mendorong Pertumbuhan Ekonomi yang Adil dan Berkelanjutan. Jurnal Kebijakan Ekonomi, 1 (3): 217-234.

13. Hidayat, S. dan A.E.Nugroho.2010. Dilema Investasi dan Rasio Politik Keuangan Daerah : Studi Kasus di Provinsi Kepulauan Riau. Jurnal Bhineka Tunggal lka. 1 (1): 101-125.

14. Hoessein, B. 2001. Prospek Resolusi Kebijakan dan Implementasi Otonomi Daerah dari Sudut Pandang Hukum Tata Negara. Jurnal Ekonomi dan Pembangunan, 9 (2) : 1-19.

15. Legowo, S. P. 2009. Infrastruktur Transportasi: Keterkaitan Antar Wilayah dan Pertumbuhan Ekonomi di Wilayah Jakarta, Bogor, Depok, Tangerang dan Bekasi. Doctoral Dissertation, Program Studi IImu Ekonomi Pertanian, Sekolah Pascasarjana, Institut Pertanian Bogor, Bogor.

16. Mangkoesoebroto. G.2013. Ekonomi Publik. Badan Penerbit Fakultas Ekonomi Universitas Gajah Mada, Yogyakarta.

17. Nanga, M. 2006. Dampak Transfer Fiskal terhadap Kemiskinan di Indonesia; Suatu Analisis Simulasi Kebijakan. Doctoral Dissertation, Program Studi IImu Ekonomi Pertanian, Sekolah Pascasarjana, Institut Pertanian Bogor, Bogor.

18. Pakasi, C.B.D. 2005. Dampak Desentralisasi Fiskal Terhadap Perekonomian Kabupaten dan Kota di Provinsi Sulawesi Utara. Doctoral Dissertation, Program Studi Ilmu Ekonomi Pertanian, Sekolah Pascasarjana, Institut Pertanian Bogor, Bogor.

19. Panjaitan, M. 2006. Dampak Desentralisasi Fiskal terhadap Kinerja Perekonomian Daerah Kabupaten dan Kota di Provinsi Sumatera Utara: Suatu Pendekatan Ekonometrika. Doctoral Dissertation, Program Studi Ilmu Ekonomi Pertanian, Sekolah Pascasarjana, Institut Pertanian Bogor, Bogor.

20. Pardede, R. 2004. Dampak Investasi Swasta terhadap Kinerja Perekonomian Kabupaten Tapanuli Utara. Doctoral Dissertation, Program Studi Ilmu Ekonomi Pertanian, Sekolah Pascasarjana, Institut Pertanian Bogor, Bogor.

21. Purwanto. 2009. Pemibayaan Pembangunan Daerah dalam Perekonomian Regional. Jurnal Ekonomi dan Pembangunan, 17 ( 2),: 34-60. 
22. Purbadharmaja. 2006. Implikasi Variabel Pengeluaran dan Investasi Terhadap Pertumbuhan Ekonomi Propinsi Bali. Jurnal Buletin Studi Ekonomi Vol .11 No.1: 79-91. ISSN1410-4638.

23. Riyanto dan H. Siregar. 2005. Dampak Dana perimbangan terhadap Perekonomian Daerah dan Pemerataan Antarwilayah. Jurnal Kebijakan Ekonomi, 1 (1): 15-35.

24. Romer, D. 2001. Advanced Macroeconomics. Second Edition, McGraw-Hill, International Addtion, New York.

25. Rosen, H.S. 2002. Public Finance. Sixth Edition. McGraw Hill, Irwin, Boston.

26. Rowa, H. 2003. Laporan Penelitian Evaluasi Implementasi Kebijakan Otonomi Daerah dalam Rangka Percepatan Desentralisasi. Jurnal IImu Pemerintahan, Widyapraja, 29 (3):220-235.

27. Samuelson, P.A, \& Nordhaus, W, D. 2004. Ilmu Makroekonomi, Edisi ketujuhbelas, alih bahasa Gretta dkk. Jakarta : PT Media Global Edukasi.

28. Simanjuntak, R. 2010. Desentralisasi Fiskal dan Manajemen Makroekonomi: Urgensi Suatu Grand Design di Indonesia. Prisma, 29 (3): 35-57.

29. Sodik Jamzani. 2007. Pengeluaran Pemerintah dan Pertumbuhan Ekonomi Regional : Studi Kasus Data Panel di Indonesia. Jurnal Ekonomi Pembangunan Vol.12 No.1 : 2736.

30. Sitepu, R. K., dan B. M. Sinaga. 2007. Aplikasi Model Ekonometrika: Estimasi, Simulasi dan Peramalan Menggunakan SAS. Program Studi IImu Ekonomi Pertanian, Sekolah Pascasarjana, Institut Pertanian Bogor, Bogor.

31. Sodik, J. 2007. Pengeluaran Pemerintah dan Pertumbuhan Ekonomi: Studi Kasus Data Panel Indonesia. Jurnal Ekonomi Pembangunan, 12 (1) : 27-36.

32. Sularso H. \& Restianto Y.E. 2011. Pengaruh Kinerja Keuangan Terhadap Alokasi Belanja Modal dan Pertumbuhan Ekonomi Kabupaten/Kota di Jawa Tengah. Jurnal Media Riset Akuntansi , Vol. 1 No. 2 : 109-124.

33. Tambunan Tulus T.H. 2011. Perekonomian Indonesia. Bogor : Penerbit Ghalia.

34. Todaro, M. and S.C. Smith. 2006. Economic Development: Ninth Edition. Addison Wesley Harlow, Boston.

35. Undang-Undang Nomor 33 Tahun 2004 tentang Perimbangan Keuangan antara Pemerintah Pusat dan Daerah.

36. Usman. 2006. Dampak Desentralisasi Fiskal terhadap Distribusi Pendapatan dan Tingkat Kemiskinan. Master's Thesis, Program Studi IImu Ekonomi Pertanian, Sekolah Pascasarjana, Institut Pertanian Bogor, Bogor.

37. Waluyo, J. 2007. Dampak Desentralisasi Fiskal terhadap Pertumbuhan Ekonomi dan Ketimpangan Pendapatan antardaerah di Indonesia. Bahan Parallel Session IA : Fiscal Decentralization, Wisma Makara, Kampus UI - Depok, .

38. Vibiz Regional Research. 2008. Pembangunan Infrastruktur dan Pertumbuhan Ekonomi Regional Kawasan Timur Indonesia. (http:Ilwww.beritadaerah.com).

39. Yudhoyono, S. B. 2004. Pembangunan Pertanian dan Perdesaan Sebagai Upaya Mengatasi Kemiskinan dan Pengangguran : Analisis Ekonomi Politik Kebijakan Fiskal. Doctoral Dissertation, Program Studi Ilmu Ekonomi Pertanian, Sekolah Pascasarjana, Institut Pertanian Bogor, Bogor.

40. Yustika, E. A. 2007. Desentralisasi Ekonomi di Indonesia: Kajian Teoritis dan Realitas Empiris. Bayumedia, Malang

41. Zhang,T. dan H. Zou. 1996. Fiscal Decentralization, Public Spending, and Economic Growth in China. Policy Research Working Paper No.1608, The World Bank, Public Economics Division, Washington, D.C. 